\title{
Acceptability of a COVID-19 pre-exposure prophylaxis trial with hydroxychloroquine in French healthcare workers during the first wave of COVID-19 pandemic
}

\author{
Amandine Gagneux-Brunon ${ }^{1,2}$, Clémentine Schilte ${ }^{3}$, Arnauld Garcin ${ }^{4}$, Nathalie Jolly ${ }^{3}$, Muriel Vray $^{5}$, Laura Schaeffer ${ }^{5}$,
} Xavier Duval ${ }^{6}$, Bruno Hoen ${ }^{7}$ and Elisabeth Botelho-Nevers ${ }^{1,2^{*}}$ (D)

Keywords: Pre-exposure chemoprophylaxis trial, SARS-CoV-2 infection, Healthcare workers, Acceptability, Hydroxychloroquine

Healthcare workers (HCWs) have been over-represented among people infected with Severe Acute Respiratory Syndrome-Coronavirus-2 (SARS-CoV-2). In France, between March 1 and November 2, 2020, SARS-CoV-2 infection was diagnosed in more than 44,000 HCWs and killed 17 [1]. In the USA, HCWs accounted for around $20 \%$ of the confirmed cases of SARS-CoV-2 infections by April 2020 [2]. Protection of HCWs rapidly became a crucial challenge during the COVID-19 pandemics [3]. Pre- and post-exposure chemoprophylaxis was considered to be used in addition to personal protective equipment. More than 50 clinical trials aiming to assess chloroquine or hydroxychloroquine (HCQ) in HCWs and/or household contacts of COVID-19 cases have been registered worldwide with ClinicalTrials.gov. In France in April 2020, a multi-center randomized, double-blind, placebo-controlled trial to evaluate the efficacy of a 2-month pre-exposure prophylaxis with HCQ in $600 \mathrm{HCWs}$ exposed to COVID-19 patients was started [4]. This trial was funded by the French hospital program for clinical research (PHRC) and sponsored by

\footnotetext{
* Correspondence: elisabeth.botelho-nevers@chu-saint-etienne.fr

'Department of Infectious diseases, University Hospital of Saint-Etienne, Saint-Etienne, 42055, France

${ }^{2}$ CIC-1408 Vaccinology, INSERM, University Hospital of Saint-Etienne, Saint-Etienne, 42055, France

Full list of author information is available at the end of the article
}

the University Hospital of Saint-Etienne in collaboration with Institut Pasteur in Paris. For each participant, six visits at the investigation center, one weekly electrocardiogram, 5 blood samplings, and 4 nasopharyngeal swabs for SARS-CoV-2 RT-PCR were scheduled. Before the trial started, we conducted an anonymous online survey in ten of the investigation centers to evaluate the acceptability of the trial among HCWs, whether they worked in a hospital, an ambulatory setting, or a long-term care facility. Eight hundred and seventy-one HCWs completed the survey. Among respondents, 695 (79.8\%) reported they were interested in participating in the trial. Intention to participate was not influenced by age or working place. Among the 695 potential volunteers, 430 $(61.9 \%)$ were under 45 years of age and only $126(18.1 \%)$ reported a significant comorbidity. The main reasons for declining participation in the study were the following: (1) fears about HCQ side effects in 121 of the 176 decliners (68.8\%), (2) the perception that the individual risk of severe COVID-19 was low in 36 (20.5\%), (3) the constraints resulting from the number of study visits in 29 (16.5\%), and (4) the burden of nasopharyngeal swabs for SARS-CoV-2 RT-PCR in 25 (14.2\%). Six hundred and ninety-five respondents reported being interested in participating in the chemoprophylaxis trial, and 117 were actually enrolled by May 27, 2020. In the first center where the trial was started, $342 \mathrm{HCWs}$ reported being 
interested in participating in the trial and 91 were enrolled between April 14 and May 27 2020, when the French Medicine Agency put all trials evaluating HCQ on hold.

After the French Medicine Agency's decision and as the French epidemic curve was decreasing and the recruitment became challenging, the trial was stopped. This work shows that, at the time the survey was launched, French HCWs were prone to participate in a SARS-CoV-2 infection chemoprophylaxis trial with HCQ, although fear of side effects was the primary reason to decline study participation. This information was key in our decision to start the trial.

After two randomized, double-blind, placebocontrolled trials showed no protective effect of HCQ in HCWs exposed to SARS-CoV-2 [5, 6], it is now admitted that HCQ is unlikely to act as a prophylactic agent against COVID-19. However, the evaluation of other agents and regimens would still be of interest in highrisk people until effective vaccines are widely available. Given the acceptability rate we observed in our survey, the feasibility of clinical trials on chemoprophylaxis of COVID-19 in HCWs appears reasonably fair. Nevertheless, we suggest that before starting trials involving hundreds of volunteers, surveys need be conducted to assess participants' acceptability and preferences among preventive strategies to be tested.

\section{Acknowledgments}

The authors thank all investigators that contribute to broadcast the survey in an around their centers.

\section{Authors' contributions}

EBN is the chief investigator and $\mathrm{BH}$ the scientific director of the trial COVIDAXIS. For the study of acceptability reported here, EBN and AGB conceived the questionnaire. AG, NJ, MV, LS, XD, and BH reviewed it. AGB, EBN, and CS created it on Lime survey, and EBN and CS contributed to the diffusion of the survey. The authors read and approved the final manuscript.

\section{Funding}

The Trial COVIDAXIS was supported by a grant from the French Ministry of Health (SERI-COVID-I 2020-0355). The sponsor of this study is CHU de SaintEtienne. The study of acceptability reported here have no specific funding.

\section{Availability of data and materials}

EBN and AGB have access to the final database of acceptability study reported here.

\section{Declarations}

Ethics approval and consent to participate

Acceptability study reported here, performed in link to the trial COVIDAXIS (NCT04328285) was approved by the Ethics committee of University Hospital of Saint-Etienne (IRBN822020/CHUSTE.). Here, we do not report results of COVIDAXIS trial (trial that was approved by CPPIDF1-2020-ND47).

\section{Consent for publication}

Not applicable.

\section{Competing interests}

The authors declare that they have no competing interests.

\section{Author details}

'Department of Infectious diseases, University Hospital of Saint-Etienne, Saint-Etienne, 42055, France. ${ }^{2} \mathrm{CIC}-1408$ Vaccinology, INSERM, University Hospital of Saint-Etienne, Saint-Etienne, 42055, France. ${ }^{3}$ Center for

Translational Science, Institut Pasteur, Paris, France. ${ }^{4}$ Unité de Recherche Clinique, Innovation et Pharmacologie, University Hospital of Saint-Etienne, Saint-Etienne, 42055, France. ${ }^{5}$ Unité d'Epidémiologie des Maladies Emergentes, Institut Pasteur, INSERM, Paris, France. ${ }^{6}$ Inserm CIC-1425, AP-HP, Hôpital Universitaire Bichat; Inserm UMR-1137 IAME; Université Paris Diderot, UFR de Médecine-Bichat, Paris, France. ${ }^{7}$ Institut Pasteur, Paris, France.

Received: 18 November 2020 Accepted: 18 May 2021

Published online: 30 May 2021

\section{References}

1. Recensement national des cas de COVID-19 chez les professionnels en établissements de santé [Internet]. [cited 2020 Nov 9]. Available from: https://www.santepubliquefrance.fr/etudes-et-enquetes/recensement-na tional-des-cas-de-covid-19-chez-les-professionnels-en-etablissements-de-sa nte.

2. CDC COVID-19 Response Team. Characteristics of health care personnel with COVID-19 - United States, February 12-April 9, 2020. MMWR Morb Mortal Wkly Rep. 2020;69(15):477-81.

3. The Lancet. COVID-19: protecting health-care workers. Lancet. 2020; 395(10228):922. https://doi.org/10.1016/50140-6736(20)30644-9.

4. Chemoprophylaxis of SARS-CoV-2 Infection (COVID-19) in exposed healthcare workers - full text view - ClinicalTrials.gov [Internet]. [cited 2020 Jul 3]. Available from: https://clinicaltrials.gov/ct2/show/NCT04328285.

5. Abella BS, Jolkovsky EL, Biney BT, Uspal JE, Hyman MC, Frank I, et al. Efficacy and Safety of Hydroxychloroquine vs Placebo for Pre-exposure SARS-CoV-2 Prophylaxis Among Health Care Workers: A Randomized Clinical Trial. JAMA Intern Med. 2021;181(2):195-202.

6. Rajasingham R, Bangdiwala AS, Nicol MR, Skipper CP, Pastick KA, Axelrod $\mathrm{ML}$, et al. Hydroxychloroquine as pre-exposure prophylaxis for COVID-19 in healthcare workers: a randomized trial. Clin Infect Dis. 2020:ciaa1571.

\section{Publisher's Note}

Springer Nature remains neutral with regard to jurisdictional claims in published maps and institutional affiliations.
Ready to submit your research? Choose BMC and benefit from:
- fast, convenient online submission
- thorough peer review by experienced researchers in your field
- rapid publication on acceptance
- support for research data, including large and complex data types
- gold Open Access which fosters wider collaboration and increased citations
- maximum visibility for your research: over $100 \mathrm{M}$ website views per year
At BMC, research is always in progress.
Learn more biomedcentral.com/submissions 